\title{
Speak Out Your Films: \\ When Asian Independent Film Festivals Send Messages to the World
}

\author{
Zaki Habibi \\ Dosen Program Studi Ilmu Komunikasi \\ Universitas Islam Indonesia (UII), Yogyakarta
}

\begin{abstract}
This article focuses on three independent film festivals held in three different countries in Asia. They are (1) Jeonju International Film Festival (JIFF) in Jeonju, South Korea, (2) Cinemalaya Philippine Independent Film Festival in Manila, The Philippines, and (3) Jogja-NETPAC Asian Film Festival (JAFF) in Yogyakarta, Indonesia. Multiple case studies is adopted to analyse the way in which these three independent film festivals are being organised, including the "messages" being circulated for their global audiences. The findings are analysed based on the conceptual framework that consists of three relevant concepts: film as cultural product, independent film festival, and cultural discourse. The conclusion shows that the three analysed film festivals offer an alternative way in film distribution, then demonstrate unconventional way of festival organising, and strengthening the power of community and its networks as the basis for the development of their festivals.
\end{abstract}

Keywords: Film distribution, film festival, independent, community, case study

\begin{abstract}
Abstrak
Artikel ini menyoroti tiga festival film independen di tiga negara di Asia sebagai fokus studi. Ketiganya adalah (1) Jeonju International Film Festival (JIFF) di Jeonju, Korea Selatan, (2) Cinemalaya Philippine Independent Film Festival di Manila, Filipina,dan (3) Jogja-NETPAC Asian Film Festival (JAFF) di Yogyakarta, Indonesia. Kajian terhadap penyelenggaraan ketiga festival film independen tersebut dilakukan dengan mengadopsi pendekatan studi kasus berganda (multiple case studies). Pada tingkat analisis, seluruh temuan relevan dari ketiganya ditelaah lebih jauh melalui kerangka konseptual yang berbasis pada tiga sumbu, yakni film sebagai produk budaya, festival film independen, dan diskursus kultural. Muaranya, ketiga festival film di Asia ini ternyata menawarkan sistem alternatif dalam ranah distribusi film, lalu mempraktikkan cara yang tidak konvensional dalam mengelola sebuah festival, serta mendayagunakan komunitas dan jejaringnya sebagai basis pengembangan masing-masing festival tersebut.
\end{abstract}

Kata Kunci:Distribusi film, festival film, independen, komunitas, studi kasus 


\section{Introduction}

Most major international film festivals, both in the United States (US) and Europe, have considerable contributions to film distribution around the world. This is the part of cinema mechanisms in terms of film as the industry where film festivals boost the scope of distribution and increase the income for cinema industry while, at the same time, create the standards of aesthetic values and qualities. This notion, however, is not the main motivation for several film festivals in Asia. There are many Asian film festivalsorganised by Asian committees in Asian countries-that are dedicated for other motivations rather than economic interest in regard to industrial objectives. This kind of film festivals, then, can be simply recognised as the independent film festivals.

The Asian independent film festivals provide the alternative way of film distribution, offer the unconventional system on managing a film festival, and empower the strength of community as a new basis of its development. This is the main thesis of the essay that encourages several follow-up questions: how do they manage the festivals? Why does this system influence the motivations beneath every event and affect the cinema development both locally and internationally?

\section{The Methodology}

This study generally adopts the case study as its method. The study focuses on three film festivals in different countries in Asia, and it leads to "multiplecase studies" as the specific method applied here because there are three different unit analyses with a few basic similarity in one hand and several significant differences on the other hand (Yin, 2003: 46). The method used here, then, generates the research report by applying "replication logic" (Yin, 2003: 47) to reinforce the findings and construct the conclusion. This essay as the report is presented in a logical order, started by a concise explanation of the conceptual framework, a brief description of each festival, the main characteristics, the comparison among them in terms of its history (establishment motivation), the goal, the type of films that have been screened, the supporting events (the fringes), the people behind the screen (the organisation and the management system), the funds (the event supporters), the socio-political and cultural position in the country where it is held, and the impacts towards the cinema development and cultural discourses.

The three analysed film festivals are (1) Jeonju International Film Festival (JIFF) held in Jeonju, South Korea; (2) Cinemalaya Philippine Independent Film Festival held in Manila, the Philippines; and (3) Jogja-NETPAC Asian Film Festival (JAFF) in Yogyakarta or Jogja, Indonesia. 
The main reason regarding these chosen film festivals is because all of the three countries have a long history of cinema industry that create complex circumstances and emerge diverse film styles and filmmakers. On the other hand, all of the countries demonstrate different conditions in regard to the film development, world recognition to their cinema, and cultural discourses they constructed. According to these interesting conditions, these choices are made as the basis for the further analysis of this study.

\section{The Conceptual Framework}

There are three relevant concepts used in this research; film as a cultural product, independent film festival, and cultural discourse. The linkage among these concepts constructs a conceptual framework as the approach to analyse the findings collected throughout the study. The conclusion, then, is integrated based on an in-depth interpretation using this conceptual framework regarding the comparison of the three film festivals. A brief explanation relating to the concepts can be seen below respectively.

\section{Film as a Cultural Product}

Film, in general context, can be seen as "three important subjects" (Riri Riza, personal communication, November
16, 2005) ${ }^{1}$. First, it is a form of arts that represents the artists' expressions in regard to their views about giving meaning to their life and also to the world where they live in. The term artist here usually refers to the filmmaker. Second, film can be understood as a medium of communication, specifically as a mass media. The relation and meaning construction between its creator and audience have considered film as a significant medium in communication processes. The third is film as a cultural product. Since a film is produced with intention to be shown to others, this leads film to a wider discussion in terms of cultural matters. Film has been distributed and shown to others either in mass consumption style or in a specific community only. The process of dialogue between film (as cultural text) and the people, then, tends to give considerable impacts to these people and also to the development of cinema itself. At this

\footnotetext{
${ }^{1}$ Riri Riza is one of Indonesian acclaimed film directors. His works, for example, Kuldesak [Culde-sac] (released in 1998), Petualangan Sherina [The Adventure of Sherina] (2000), Eliana, Eliana (2002), Gie (2005), 3 Hari untuk Selamanya [3 Days for Forever] (2007), Laskar Pelangi [Rainbow Squad] (2008), and Sang Pemimpi [The Dreamer] (2009), have become Indonesian box office and invited constructive critics in terms of alternative film genre and new hope of Indonesian cinema. He is also a film activist, the co-founder of Masyarakat Film Indonesia (the Indonesian Film Society), that fight for freedom of expression and distribution in Indonesian film industry and, also, promoting the replacement of strict censorship with film classification. The personal communication quoted here is based on my interview with him after he finished his speech in a seminar in Surabaya, East Java, Indonesia on November 16, 2005.
} 
point, film has become a text within context that no longer put film as a form of the arts only, or a communication medium, but also has important contribution in culture.

\section{Independent Film Festival}

The discussion about independent film festival should be based on the broader meaning of independent in cinema itself. It is started with the meaning of independent film or independent cinema. Blandford, Grant, and Hillier (2001: 131) explain that 'independent' in cinema has various meanings. However, the similarity of these diverse meanings is the way in which filmmakers or the people behind the filmmaking process do not depend upon "major studio system" in terms of production management, budgeting, and distribution (Blandford,Grant, and Hillier,2001: 131). In the US, ironically, after the 1980's several independent filmmakers or producers being supported by major studios, especially their film distributions. In the European countries such as the UK and France, the independent films have their specific place for screening called "art house" that mostly shows art films or non-mainstream cinema that produced independently (Blandford,Grant, and Hillier, 2001: 14).

However, the situation occurs in Asian countries is completely different. Indeed, the cinema industry in Asia has already had a long history as well as in the US and Europe. For instance, South Korea had their first "movie house" in 1906 and first Korean movie production in 1919 (Lent, 1990: 124) while Philippines began to screen a foreign movie on 1 January 1897 then establishedthe Board of Censorship for Cinematographic Films in 1911 and produced their own feature film in the following year (Lent, 1990: 150). A similar condition has also taken place in Indonesia where they hadits first feature film production in 1926 called Loetoeng Kasaroeng (Lent, 1990: 203). Despite these long history, however, the cinema industry in these three Asian countries is operated in different way with what developed in the US and Europe. There is no major studio system because films are produced based on the producer team or filmmaker initiatives. The system that can be called as the mainstream cinema in these Asian countries is the film industry that operates on a big budget supported by either government or private investors then nationally distributed through main theatre networks in a monopolistic or oligarchic system.

In general, the independent movement in these three respective countries appears since the 1990's in order to oppose this monopolistic or oligarchic practice. Besides, the movement also takes place to raise public awareness that film is a public domain that has its socio-cultural context rather than just an economic commodity. The independent films 
produced in these Asian countries also represent the movement of younger generation especially that offer an alternative system for building the cinema industry in the country.

These young independent filmmakers and producers need another distribution system due to the limitation for screening their works in so-called mainstream theatres. The film festival, then, is seen as a good solution to gain appreciation from broader audience. The film festivals held in such purpose are also managed and funded independently to promote alternative films and develop wider appreciation about the unconventional cinema in terms of the genre and production-distribution system. Thiskind of film festivals-emerged in South Korea, Philippines and Indonesiaare called as the independent film festivals.

\section{Cultural Discourse}

The third concept that functions as the unique identification of the subjects of this multiple-case studies is cultural discourse. This concept is a further adaption of "discourse" that is mainly proposed by a French historian and philosopher, Michel Foucault. David Howarth (2000: 67) who writes an exhaustive study about the theory of discourse describes Foucault's thought that "the concept of discourse is still widely deployed, although discourses are no longer treated as autonomous systems of scientific statements, but the products of power relations and forces that form them". In other words, Foucauldian discourse is determined by "social practices and the way they in turn shape social relationships and institutions" (cited in Howarth, 2000: 8).

I adapt the "political discourse" introduced later by Foucault to be reformulated intocultural discourse to interpret the cultural position and meaning construction caused by the three Asian independent film festivals. As Foucault says, scientific discourse that become his first study to seek how discourses are shaped has turned into further examination where "the way in which political practices modify and transform the rules of formation of scientific discourse (cited in Howarth, 2000: 60-61). Thus, "Foucault stresses the way discourses partly form social relations, identities, and social objects" (Howarth, 2000: 81). By this I mean, the role of these film festivals in terms of constructing the cultural context in each country has a similar form to the formulation process of discourses. In other words, it leads to another concept called the cultural discourse. 


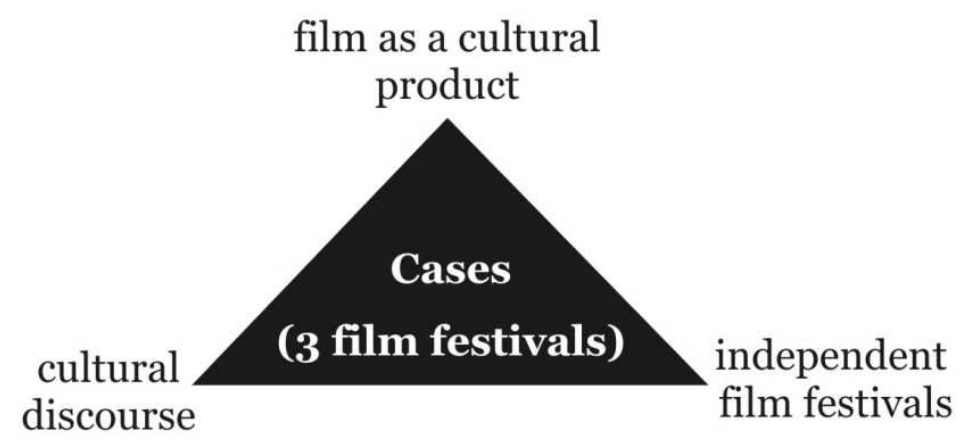

Figure 1. The Conceptual Framework

The Film Festivals, Stories from Three Asian Countries

\section{Jeonju International Film Festival (JIFF)}

JIFF is held in Jeonju, known as a cultural city in Jeollabuk-do province, located in the north part of South Korea. The JIFF Committee has been conducting this festival since 2000, and the festival usually takes place in the spring for a whole week. The $12^{\text {th }}$ JIFF was held from 29 April 2011 to 5 May 2011. Jeonju that has 630,000 inhabitants is also a famous city due to their traditional Korean foods and artists (Sasono, 2010a).The festival takes place in four separated theatres, Megabox, CGV, Jeonju Cinema Town, and Chonbuk University. The first three are located in a same street named Cinema Street. All major events whether the film screening or any additional events such as music performances and film market are situated in this street.

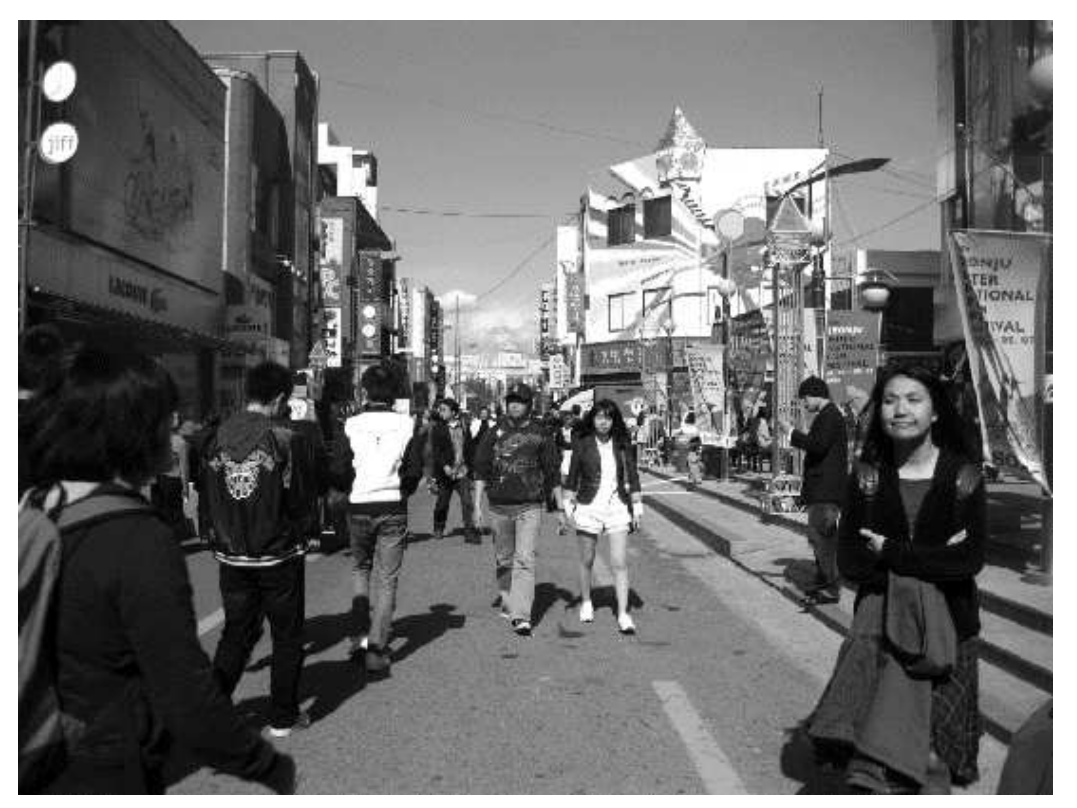

Figure 2. The Cinema Street in Jeonju, South Korea (Sasono, 2010a) 
JIFF is not a big festival as compared to Busan International Film Festival in Busan, South Korea. However, JIFF is a considerable film festival especially because of its focus in giving a major role for "independent and experimental films" mostly made by young filmmakers from around the world (Sasono, 2010a). Eric Sasono, a film critic who was appointed as one of the juries in JIFF 2010, says that this festival provides a wide opportunity for "aesthetic breakthroughs in cinema, obscure cinema and experimental filmmaking" (2010a).

Based on this vision, JIFF promotes its well-known programmes called Jeonju Digital Project (JDP) and Jeonju Project Market (JPM). JDP is a yearly funded project by JIFF Committee for three filmmakers around the world who are challenged to produce an unconventional digital video project. JDP is a leading project in JIFF that provides 50 million Korean won (approximately US \$50,000) for supporting the production of three digital video projects in 30 minutes length of each film (Sasono, 2010b).

Meanwhile, JPM is a film market session that seeks and supports the Korean independent films both feature fiction films and documentaries to be distributed and screened in a broader opportunity. The programme also promotes these Korean productions to the international market "as well as exploring the possibilities of distribution in Korea for outstanding film from overseas" (“JPM
Overview", 2011). The Festival Chairman, Ha-jin Song, and the Festival Director, Byung-lock Min, say that by promoting JDP and JPM as JIFF's unique programmes they want to sustain JIFF position as a film festival that addresses the "flow and changes in the film industry" by maintaining this distinctive film production and distribution system (Song and Min, 2011). In their words, this effort is another way to reinforce JIFF's role "as one of the most important film festivals in Asia and a window of independent and experimental films around the world" (Song and Min, 2011).

Besides, JIFF has a competition programme that usually consists of 10 to 12 films that have been chosen by festival programmers. They do not distinguish and categorise these films according to genre, for example, so there is no strict classification between feature fiction film and documentary. What they are looking for is a new and insightful exploration in terms of cinematic approaches and presentations rather than common regular achievements.

\section{Cinemalaya Philippine Independent Film Festival}

The next film festival analysed here is Cinemalaya Philippine Independent Film Festival (hereafter called Cinemalaya). The festival that is held in the capital city of Philippines, Manila, has been running for the last seven years 
(until 2011). Cinemalaya takes place in the Cultural Centre of the Philippines and is held for nine-day long every July.

According to the organising committee, the aim of this festival is "to encourage the creation of new cinematic works by Filipino filmmakers" and also to revitalise "the Philippine filmmaking by developing a new breed of Filipino filmmakers" (Cinemalaya, n.d.). The committee selects and grants ten young Philippine talents to make their feature films, then, their works will be screened and competed within the festival.

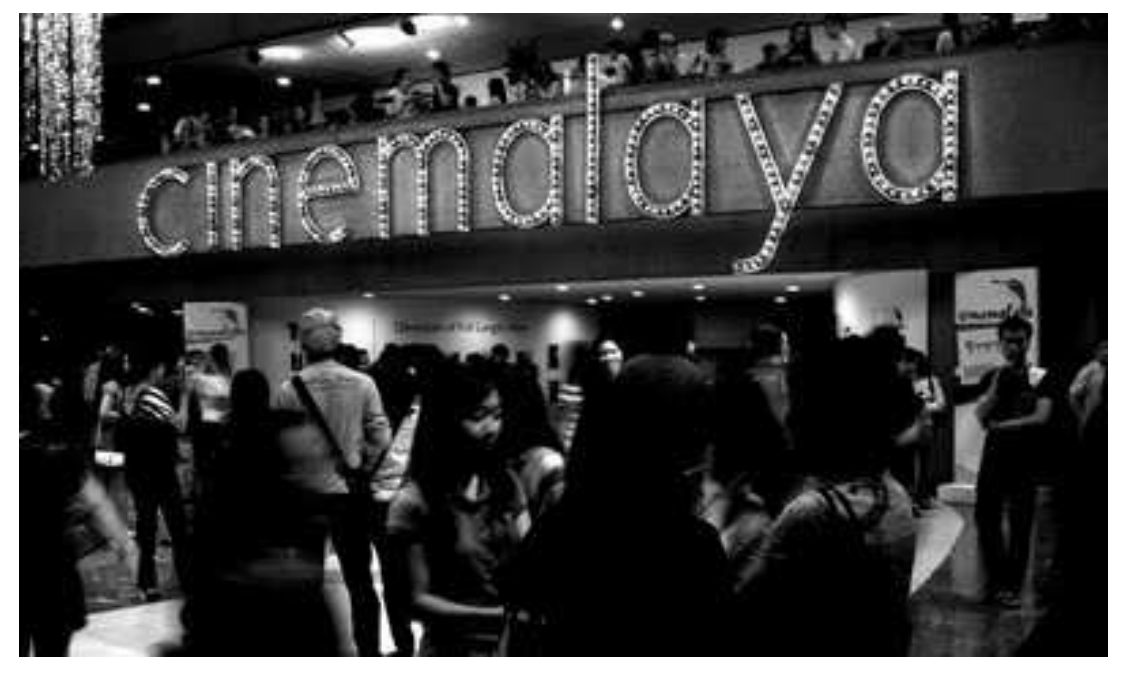

Figure 3. Cinemalaya crowded by the audience

Apart from this screening programme, Cinemalaya conducts the fringe or other film-related events, such as "the Cinemalaya Film Congress, a two-day conference that looks at all aspects of independent filmmaking and distribution; the Cinemalaya Sine Taktakan, a forum with the year's batch of new Cinemalaya filmmakers"; and other art events (Cinemalaya, n.d.).Cinemalaya is organised and supported by The Cinemalaya Foundation that defines them as "a non-stock, not-for-profit, nongovernmental foundation who committed to the development and promotion of Philippine Independent film”
(Cinemalaya, n.d.). The Foundation has a main core in helping and assisting the "production of cinematic works of Filipino independent filmmakers that boldly articulate and freely interpret the Filipino experience with fresh insight and artistic integrity", while also giving assistance to the process of "discovering, encouraging, supporting, training, and recognising gifted Filipino independent filmmakers and to promote Filipino independent films locally and internationally"; they also provide opportunity to develop "a network for exchange, communication and cooperation among members of the 
independent film sector" (Cinemalaya, n.d.).

\section{Jogja-NETPAC Asian Film Festival (JAFF)}

JAFF was a collaborative initiative between an Indonesian critically acclaimed director, Garin Nugroho, Network for the Promotion of Asian
Cinema (NETPAC), and film communities in Yogyakarta or commonly called Jogja, Indonesia, in 2006 (Network for the Promotion of Asian Cinema [NETPAC], n.d.). This tripartite collaborationorganises an annual Asianscaled film festival in Jogja, a cultural province and also the second famous tourism attraction in Indonesia after Bali.

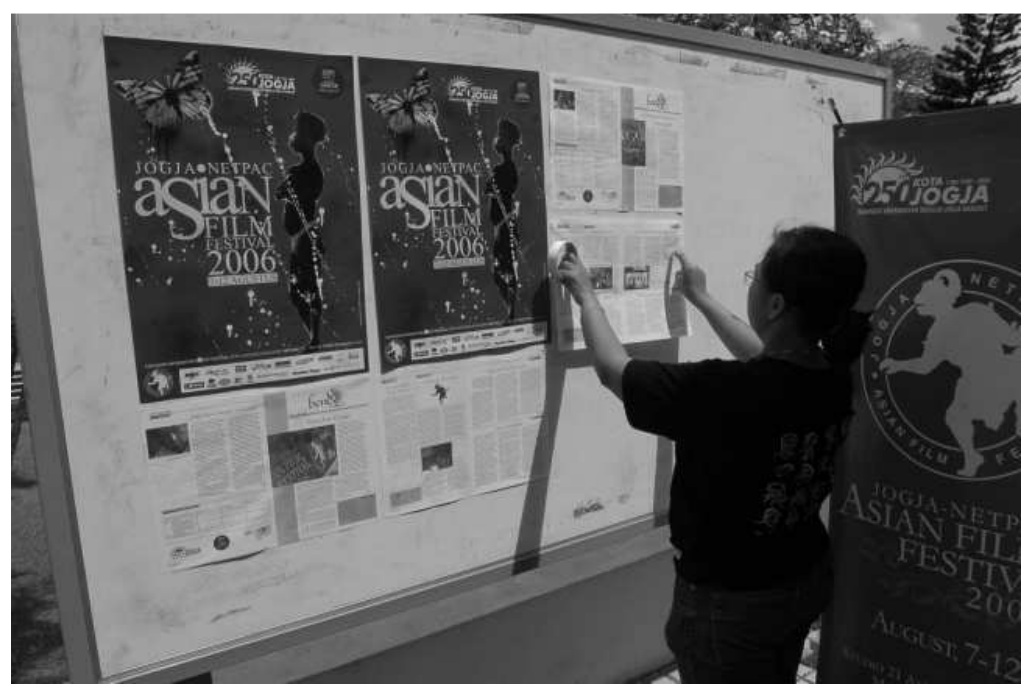

Figure 4. A volunteer put a daily bulletin during the first event of JAFF in 2006 (Source: personal collection)

The main aim of this film festival is to promote Asian cinema both in Asia and the world. On the other hand, this is also a festive moment for all film communities in Indonesia whether they are filmmakers, critics, or moviegoers. The Festival President, Garin Nugroho, labels this event as "when-a-moment-of-creation meets the-moment-of-appreciation" (Garin Nugroho, personal communication,
August 7, 2006) ${ }^{2}$.JAFF has several programmes, such as Asian Feature (main Asian film competition), Light of Asia (short film competition), Public Lecture (series of film-related seminar and workshop), Jogja Camp (a film community forum) and several collaborative events with many local organisations in this city

\footnotetext{
${ }^{2}$ The personal communication quoted here based on an interview with Garin Nugroho, a few hours before the opening of the first JAFF on August 7, 2006 in Yogyakarta (Jogja), Indonesia.
} 
(Jogja-NETPAC Asian Film Festival comparison is a further step of this [JAFF], n.d.). multiple-case study. The comparison can be seen in the table below.

\section{Findings and Analysis: Significant Features and the Comparison}

The facts from all film festivals can be compared one to another. This

Table 1. The Comparison of Three Asian Independent Film Festivals

\begin{tabular}{|c|c|c|c|c|}
\hline No. & Aspects & $\begin{array}{c}\text { JIFF } \\
\text { (South Korea) }\end{array}$ & $\begin{array}{l}\text { Cinemalaya } \\
\text { (Philippines) }\end{array}$ & $\begin{array}{c}\text { JAFF } \\
\text { (Indonesia) }\end{array}$ \\
\hline 1 & $\begin{array}{l}\text { Year of } \\
\text { establishment }\end{array}$ & - 2000 & - 2004 & - 2006 \\
\hline 2 & $\begin{array}{l}\text { The goal } \\
\text { (the main } \\
\text { character) }\end{array}$ & $\begin{array}{l}\text { - Cinematic exploration } \\
\text { and experimentation }\end{array}$ & $\begin{array}{l}\text { - Supporting local } \\
\text { independent } \\
\text { cinema }\end{array}$ & $\begin{array}{l}\text { - Promoting Asian } \\
\text { cinema }\end{array}$ \\
\hline 3 & $\begin{array}{l}\text { Type of films that } \\
\text { have been screened }\end{array}$ & $\begin{array}{ll}\text { - } & \text { International } \\
\text { - } & \begin{array}{l}\text { Experimental and } \\
\text { obscure films }\end{array}\end{array}$ & $\begin{array}{l}\text { - National } \\
\text { - Filipino } \\
\text { independent } \\
\text { films }\end{array}$ & $\begin{array}{l}\text { - Regional (Asia) } \\
\text { - Asian cinema both } \\
\text { fiction and } \\
\text { documentary films, as } \\
\text { well as feature and } \\
\text { shorts. }\end{array}$ \\
\hline 4 & $\begin{array}{l}\text { The fringes } \\
\text { (supporting events) }\end{array}$ & $\begin{array}{ll}\text { - } & \text { Music performances } \\
\text { - } & \text { Film market }\end{array}$ & $\begin{array}{l}\text { - Seminar } \\
\text { - Art exhibition }\end{array}$ & $\begin{array}{l}\text { - Seminar \& workshop } \\
\text { - Community forum } \\
\text { - Art performances }\end{array}$ \\
\hline 5 & $\begin{array}{l}\text { Organisation and } \\
\text { people behind it }\end{array}$ & $\begin{array}{l}\text { - Well established } \\
\text { organising and } \\
\text { managing committee } \\
\text { - } \\
\text { Supported by many } \\
\text { young volunteers }\end{array}$ & $\begin{array}{l}\text { - A well } \\
\text { established } \\
\text { foundation (The } \\
\text { Cinemalaya } \\
\text { Foundation) }\end{array}$ & $\begin{array}{l}\text { Though already have } \\
\text { foundation called } \\
\text { Yayasan JAFF, the } \\
\text { organising and } \\
\text { managing committee } \\
\text { are based on film } \\
\text { community initiatives } \\
\text { - Supported by many } \\
\text { young volunteers }\end{array}$ \\
\hline 6 & The funding & $\begin{array}{l}\text { - Self-funded (by } \\
\text { sponsorships) }\end{array}$ & $\begin{array}{l}\text { - Foundation fund } \\
\text { plus } \\
\text { sponsorships }\end{array}$ & $\begin{array}{l}\text { - Self-funded (by } \\
\text { sponsorships) }\end{array}$ \\
\hline 7 & $\begin{array}{l}\text { The "position" in } \\
\text { the country }\end{array}$ & $\begin{array}{l}\text { - Independent and be } \\
\text { positioned as the } \\
\text { "second class" festival }\end{array}$ & $\begin{array}{l}\text { - Independent and } \\
\text { be positioned as } \\
\text { the "second } \\
\text { class" festival }\end{array}$ & $\begin{array}{l}\text { - Independent and be } \\
\text { positioned as the } \\
\text { "second class" festival }\end{array}$ \\
\hline 8 & $\begin{array}{l}\text { Comparison with } \\
\text { so-called the "first } \\
\text { class" festival in } \\
\text { each country }\end{array}$ & $\begin{array}{l}\text { - Busan International } \\
\text { Film Festival in Busan }\end{array}$ & $\begin{array}{l}\text { - Cinemanila } \\
\text { International } \\
\text { Film Festival in } \\
\text { Manila }\end{array}$ & $\begin{array}{l}\text { - Festival Film Indonesia } \\
\text { (FFI) } \\
\text { - Jakarta International } \\
\text { Film Festival (JiFFEST) } \\
\text { in Jakarta }\end{array}$ \\
\hline
\end{tabular}


Based on these facts and the comparison mentioned above, the level of analysis now reaches the next step in which to seek the meaning beneath these phenomena (cases) through the conceptual framework described earlier. At first, film as a cultural product. All film festivals demonstrate the same circumstance in terms of positioning film not as an economic commodity. Although there is a film market programme in JIFF, for example, the meaning of the term 'market' here is not in the same sense as shown as in the European or North American major film markets. Rather than operatinglike a meeting point for producers, distributors and buyers, this event is more likely to be an initiation for young promising talents in local cinema in order to be heard and to be considered in a broader cinema industry.

The programme is more likely as a breakthrough to re-shape the so-called mainstream cinema industry that mostly considering profit as the main motivation of film distribution and film screening. By this festival, the committee and the participants eagerly challenge the cinema industry especially in South Korea to think about the wider meaning of film: no longer as en economic commodity only, but also has significant role in the sociocultural lives and even political one. This phenomenon also emerges in Jogja where JAFF develops a sub-programme called Film Depot (a part of the Community
Forum programme) as a meeting point for independent filmmakers, their films, and the appreciators. The depot not only deal with film transactions by selling DVD or copyright of film screening, but also concerns with forum of discussions especially to develop a further collaborative work among participants and any other young filmmakers or moviegoers.

Secondly, though the main goal, the characteristic, and the organising system of these three film festivals are relatively different, there is still one similar condition. All of these festivals work in an independent system in terms of organising, funding,andorientation. By taking this position, actually, they do not demonstrate a lack of capacities or supports. This is a role that they intentionally take part in because they still have the ideology regardless their festival scale, the aim, and the films or participants. This ideology could be giving chance to younger generation, celebrating the spirit of community, indulging viewers (audience), promoting specific cinematic genres (experimental and obscure),and focusing on cultural entity (Asian cinema).

This ideology leads to the third concept: cultural discourse. The organisers realise that the festival they organised would be compared to other bigger festival in each country. However, it is something that they pay no attention 
to. ${ }^{3}$ The notion of competition among festivals is not like the film competition within a festival itself. There is no such competition between one to another festival. Instead, they collaborate in some additional events during the festival or after the festival to promote the films and the following festival. For instance, JAFF works together with other film festivals in Indonesia, such as Jakarta International Film Festival (JiFFEST), Festival Film Dokumenter (Documentary Film Festival), and also with several film communities like Konfiden, Kampung Halaman, and Rumah Sinema. These collaborative works occur during the festival as workshops or seminars and, also, after the festival as road show for screening selected films in many universities or communities around the country. By this I mean, they perceive that film should reach many people; not only to whom that have concern on art and a part of the 'knowledge authorities'. They believe that cinema is a public domain that can reflect our lives, even constructs our hopes and dreams. In other words, they have demonstrated what Foucault says about the latest development of discourse when "power and knowledge are joined together" (cited in Howarth, 2000: 67).

\footnotetext{
${ }^{3}$ One person who supports this statement is Ajish Dibyo, the Coordinator of JAFF. As one of festival programmers he says this statement in some occasions both in formal speeches during the festival and several informal interviews with author (2006-2010).
}

Besides, all these elements show another finding especially regarding an alternative film distribution system promoted in these independent film festivals. Film distribution commonly describes as "the sector of the film industry responsible for getting films actually shown in cinemas" or being publicly exhibit (Blandford, Grant, and Hillier, 2001: 72). They continues(2001: 72), "predictably, worldwide distribution is predominantly US-based, dominated by a small number of companiesParamount, Warner, Walt Disney, Twentieth Century-Fox, Sony-Columbia and Universal". However, these three Asian film festivals show the importance of another system in film distribution that should provide equity to all genres, all cinematic styles, and especially to a younger generation of filmmakers. This system will complement another alternative system that has been predicted by Blandford, Grant, and Hillier(2001: 73) who claim that "distribution today extends beyond theatrical release and newer distribution windows ... currently digital technology is opening up new possibilities for movies-on-demand in the home as well as DVD”. The system indicated by these three Asian film festivals also addresses concern in monopolistic and oligarchic film distribution, especially in Asian countries. An Indonesian senior journalist, Rosihan Anwar-who just passed away on 14 April 2011-describes the mainstream film distribution in 
Indonesia as "a jungle where there are no rules, where everyone has to fend for himself" (cited in Lent, 1990: 209). Now his worry can be tackled step by step withthe strategythat has been demonstrated by these independent film festivals along with the young filmmakers and viewers.

\section{Conclusion}

It is clear that an optimistic view should be raised considering what have been shown in this multiple-case study on three Asian independent film festivals, JIFF in South Korea, Cinemalaya in Philippines, and JAFF in Indonesia. The notion to upraise this optimism is located in the new hope of new generation in Asian cinema in terms of creator (filmmakers) and appreciator (audience). Sasono (2010a)tells a story based on his conversation with JIFF programmer, Yoo Eun-Song, who describes that in 2009 no less than 50,000 audiences mostly the youths from Jeonju and any other cities in Korea attended the festival, while in 2010 there were 80,269 tickets sold that created 83 per cent of seat occupancy. The new generation of Korean and the world cinema are created in Jeonju through JIFF due to their focus on digital technology, cinematic explorations, and appreciation to audience (Sasono, 2010b). The similar condition also takes place in Philippines and Indonesia.
Finally, these Asian independent film festivals have already provided an alternative way of film distribution that challenges the mainstream system. They have also offered an unconventional system on managing a film festival by selffunded and voluntary supporting with promoting specific ideology. Theyhave empowered the strength of community as a new basis of its development either demonstrated by young filmmaker communities or appreciative-and-openminded audience.

\section{References}

Blandford, Steve, Barry Keith Grant, and Jim Hillier. 2001. The Film Studies Dictionary. London: Arnold.

Cinemalaya. n.d. "Cinemalaya: About Us". Accessed on 7 March 2011, http://www.cinemalaya.org/about _partners.htm

Howarth, David. 2000. Discourse. Buckingham: Open University Press.

Jogja-NETPAC Asian Film Festival [JAFF]. n.d. "JAFF: About Us". Accessed on 7 March 2011, http://jaff-filmfest.com/about-us

JPM Overview. 2011. Accessed on 7 March 2011, http://eng.jiff.or.kr/c3o_market/1 o_overview.asp 
Lent, John A. 1990. The Asian Film Industry. London: Christopher Helm.

Network for the Promotion of Asian Cinema [NETPAC]. n.d. "About NETPAC”.Accessed on 7 March 2011, http://www.netpacasia.org/(S(dpp mliix4ofma23t12rsvyup))/about.as px

Sasono, Eric. 2010a. "Festival Buat Penonton?: Catatan I dari $11^{\text {th }}$ Jeonju International Film Festival 2010[A Festival for Audience?: First Note from the $11^{\text {th }}$ Jeonju International Film Festival 2010]". Accessed on 28 February 2011, http://new.rumahfilm.org/artikelfeature/festival-buat-penontoncatatan-i-dari-11th-jeonjuinternational-film-festival-2010

Sasono, Eric. 2010b. "Rumah bagi Sinema Obskur: Catatan II dari $11^{\text {th }}$ Jeonju International Film Festival 2010 [A House for Obscure Cinema: Second Note from the $11^{\text {th }}$ Jeonju International Film Festival 2010]”. Accessed on 28 February 2011, http://new.rumahfilm.org/artikelfeature/rumah-bagi-sinemaobskur-catatan-ii-dari-11th-jeonjuinternational-film-festival-2010
Sasono, Eric. 2010c. "Fokus dan Revolusi: Catatan III dari $11^{\text {th }}$ Jeonju International Film Festival 2010 [Focus and Revolution: Third Note from the $11^{\text {th }}$ Jeonju International Film Festival 2010]”. Accessed on 28 February 2011,http://new.rumahfilm.org/ar tikel-feature/fokus-dan-revolusicatatan-iii-dari-11th-jeonjuinternational-film-festival-2010/

Sasono, Eric. 2010d. "Bakat Baru Film Korea: Catatan IV dari $11^{\text {th }}$ Jeonju International Film Festival 2010[New Talents in Korean Cinema: Fourth Note from the $11^{\text {th }}$ Jeonju International Film Festival 2010]”. Accessed on 28 February 2011, http://new.rumahfilm.org/artikelfeature/bakat-baru-film-koreacatatan-iv-dari-11th-jeonjuinternational-film-festival-2010

Song, Ha-jin, and Byung-lock Min. 2011. “Overview JIFF 2011". Accessed on 7 March 2011, http://eng.jiff.or.kr/a10_jiff/o1_s ummary.asp

Yin, Robert K. 2003. Case Study Research: Design and Methods. $3^{\text {rd }}$ ed. California: Sage Publication. 